\title{
IDENTIDADES DE GÊNERO E SEXUAIS: ANÁLISE DAS PERCEPÇÕES DE FORMANDOS EM LICENCIATURA EM CIÊNCIAS BIOLÓGICAS
}

\author{
GENDER AND SEXUAL IDENTITIES: ANALYSIS OF THE PERCEPTIONS \\ OF GRADUATES IN BIOLOGICAL SCIENCES TEACHING COURSE
}

\author{
Marco Túlio Costa Alvarenga ${ }^{1}$ \\ Luciana Resende Allain ${ }^{2}$ \\ Geraldo Wellington Rocha Fernandes ${ }^{3}$
}

\begin{abstract}
Resumo: O presente trabalho trata da temática educação e sexualidade na formação de professores de Ciências e Biologia e apresenta como foco as múltiplas identidades de gênero e sexuais. O trabalho teve como objetivo geral identificar a percepção dos formandos de um curso de Ciências Biológicas sobre seu preparo para lidar com as questões referentes às identidades de gênero e sexuais. Na pesquisa, utilizou-se da técnica de Grupos Focais para a coleta dos dados e a Análise Textual Discursiva como metodologia de análise. Verificamos que, embora estejam em um curso de formação de professores, há grande escassez de oportunidades para discutirem essa temática, tanto no curso quanto na universidade como um todo. Em consequência disso, os acadêmicos relatam não se sentirem preparados para abordar o assunto com seus futuros educandos, o que pode trazer prejuízos para a formação dos estudantes da educação básica, numa perspectiva emancipatória e de equidade.
\end{abstract}

Palavras-chave: Formação de professores; Identidades de gênero; Identidades sexuais.

\begin{abstract}
The study has the theme, of education and sexuality in the formation of Science and Biology teachers and focuses on multiple gender and sexual identities. The work had as general objective to identify the perception of the graduates of a Biological Sciences course about their preparation to deal with issues related to gender and sexual identities. In the research, it was used the technique of Focus Groups for data collection and Textual Discursive Analysis as an analysis methodology. We found that, although they are in a teacher formation course, there is a shortage of opportunities to discuss this topic, both in the course and at the university as a whole. As a result of this, academics report that they do not feel prepared to approach the subject with their future students, which can harm the education of basic education students, in an emancipatory and equity perspective.
\end{abstract}

Keywords: Teacher education; Gender identities; Sexual identities.

\footnotetext{
${ }^{1}$ Licenciando em Ciências Biológicas pela Universidade Federal dos Vales do Jequitinhonha e Mucuri (UFVJM), Diamantina, MG, Brasil. E-mail: mtalvarenga @yahoo.com.br

${ }^{2}$ Doutora em Educação pela Universidade Federal de Minas Gerais. Professora adjunta do Departamento de Ciências Biológicas da Universidade Federal dos Vales do Jequitinhonha e Mucuri, Diamantina, MG, Brasil. E-mail: luciana.allain@ufvjm.edu.br

${ }^{3}$ Doutor em Educação em Ciências pela Universidade de Lisboa, Portugal (UL). Professor adjunto no Departamento de Ciências Biológicas da Universidade Federal dos Vales do Jequitinhonha e Mucuri, Diamantina, MG, Brasil. E-mail: geraldo.fernandes.ufvjm@gmail.com
} 


\section{Introdução}

Historicamente nas escolas delegam-se aos professores e professoras de Ciências e Biologia a missão de realizar as abordagens da temática Educação Sexual, da mesma maneira a função de dialogar sobre quaisquer situações que perpassam pelas manifestações da sexualidade (SILVA; SANTOS, 2011). Isso ocorre ainda que os documentos nacionais mencionem que temáticas de caráter transversal devem ser desenvolvidas em qualquer área do conhecimento. A temática sexualidade é reconhecida nos documentos nacionais como transversal, conforme explicitado nos Parâmetros Curriculares Nacionais (PCN) (1998, p. 65) para os anos finais do ensino fundamental:

[...] os temas transversais [...] são Ética, Saúde, Meio Ambiente, Pluralidade
Cultural, Orientação Sexual e Trabalho e Consumo, por envolverem
problemáticas sociais atuais e urgentes, consideradas de abrangência nacional
e até mesmo mundial (PARÂMETROS CURRICULARES NACIONAIS,
1998, p. 65).

Apesar de nos referirmos ao previsto nos PCN, atualmente, é sabido que está em vigência para o ensino fundamental e, a partir de 2020, estará em vigor também para o ensino médio, a chamada Base Nacional Comum Curricular (BNCC) (BRASIL, 2018). Veremos que em função do conturbado cenário político vivenciado, a BNCC tem sido alvo de grandes polêmicas, em especial quanto à temática de sexualidade. Para compreender estas polêmicas, inicialmente é importante contextualizar o momento histórico-político em que estamos imersos. No cenário atual, há um crescente movimento, conhecido como "Escola Sem Partido", que de acordo com Manhas (2016) nasceu em 2004 e que vem crescendo e ganhando simpatizantes. Os adeptos defendem "a neutralidade e se dizem não partidários. No entanto, suas intenções são claras: a retroação dos avanços que tivemos nos últimos tempos, especialmente com relação aos direitos humanos" (MANHAS, 2016, p. 18). Esse retrocesso se mostrou evidente, por exemplo, durante o processo de tramitação do Plano Nacional de Educação (BRASIL, 2014), em que a principal polêmica estabelecida pelo movimento em relação ao documento foi, como salienta Manhas (2016, p. 16), “acerca da promoção das equidades de gênero, raça/etnia, regional e orientação sexual, que acabou excluída do texto do projeto".

Diversos autores do campo da educação concordam que esse movimento não corresponde à não partidarização, mas a destruição de um ambiente de debates e 


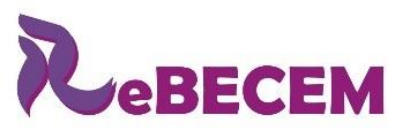

\section{Revista Brasileira de Educação em \\ Ciências e Educação Matemática}

DOI:https://doi.org/10.33238/ReBECEM.2020.v.4.n.4.25592

problematizações, de pensamento crítico, de eliminar a possibilidade de tornar a escola um local democrático e com oportunidade de diálogo acerca de temas emergentes e corriqueiros, como a sexualidade (DE ARAUJO PENNA, 2018; MANHAS, 2016). Reis e Eggert (2017, p. 12) destacam que, "a questão da orientação sexual e da identidade de gênero também ingressa no campo dos direitos humanos e, por conseguinte, no campo da educação".

Emergindo do movimento Escola Sem Partido, há uma crescente e inconsistente tese de que nas escolas vem ocorrendo a chamada "ideologia de gênero". Essa tese é fundamentada por pessoas que defendem, segundo Reis e Eggert (2017), pensamentos tradicionais e fundamentalistas acerca dos papéis de gênero do homem e da mulher e alegam que a ideologia de gênero significa a desconstrução dos papéis tradicionais de gênero e estimulam os estudantes a serem homossexuais ou transexuais. Ou seja, na perspectiva dos defensores da ideologia de gênero, discutir nas escolas acerca da temática sexualidade seria um afronte à família tradicional - pai, mãe e filhos (cisgêneros e heterossexuais ${ }^{4}$ ) e aos "bons costumes" conservadores. Porém, negar o debate da temática na escola é negar que exista sexualidade nesse ambiente. E como afirma Louro (2014):

\footnotetext{
[...] as questões referentes à sexualidade estão, queira-se ou não, na escola. Elas fazem parte das conversas dos/as estudantes, elas estão nos grafites dos banheiros, nas piadas e brincadeiras, nas aproximações afetivas, nos namoros; e não apenas aí, elas estão também de fato nas salas de aula - assumidamente ou não - nas falas e atitudes das professoras, dos professores e estudantes ( $\mathrm{p}$. $135)$.
}

Diante disso, a motivação para pesquisar a temática deve-se ao fato dos autores estarem inseridos em um curso de formação de professores em Ciências e Biologia para a educação básica, além das diversas vivências no ambiente escolar, seja através de projetos e programas, ou disciplinas de Prática como Componente Curricular. A partir de experiências pessoais dos autores na época escolar e, já no ensino superior, atuando junto ao Programa Institucional de Bolsas de Iniciação à Docência (Pibid) e ao Estágio Supervisionado, foi possível perceber que a temática sexualidade emerge com frequência no ambiente escolar. Ainda assim, muitas vezes é notório que a própria escola nega o direito dos estudantes de aprender sobre o assunto, em alguns casos tratando-o de modo preconceituoso, discriminatório e cercado de estereótipos, em especial quando se trata da homossexualidade. A título de exemplo, não é incomum os acadêmicos, ao

\footnotetext{
${ }^{4}$ Cisgêneros: pessoas que se identificam com o gênero que foi designado ao nasce; Heterossexuais: pessoas que sentem atração sexual por sujeitos do sexo oposto ao qual se identifica (JESUS, 2012).
} 
DOI:https://doi.org/10.33238/ReBECEM.2020.v.4.n.4.25592

desenvolverem estágios, escutarem dos gestores escolares: "não quero saber desses 'negócios' de homem com homem e mulher com mulher na escola". Essa fala autoritária pode cercear a liberdade dos estudantes no que tange a plena vivência de sua sexualidade e pode contribuir no reforço de estereótipos e discursos discriminatórios, o que é intolerável em uma sociedade plural como a nossa.

Em função desses desafios, esta pesquisa trata da temática educação e sexualidade na formação de professores de Ciências e Biologia, tendo como foco as múltiplas identidades de gênero e identidades sexuais. Com este trabalho, pretende-se responder a seguinte questão: os acadêmicos, formandos de um curso de Licenciatura em Ciências Biológicas de uma universidade mineira, sentem-se preparados para lidar com o ensino sobre as identidades de gênero e sexuais com seus futuros estudantes? Portanto, o objetivo principal da pesquisa foi compreender a percepção dos formandos do curso de Ciências Biológicas sobre seu preparo para lidar com as questões referentes às identidades de gênero e sexuais. Visando isso, o trabalho apresenta os seguintes objetivos específicos:

1) Identificar, na percepção dos acadêmicos, se e como o curso contribuiu para a formação dos mesmos em relação às identidades de gênero e identidades sexuais;

2) Identificar, na percepção dos acadêmicos, se houve e quais foram as vivências escolares em que eles tiveram contato com a temática;

3) Identificar se houve na universidade, durante a graduação dos estudantes, alguma vivência formativa que pode auxiliá-los no trabalho com essa temática;

4) Averiguar se os graduandos sentem-se preparados para discutir sobre as diversas identidades de gênero e sexuais com seus futuros educandos.

A relevância do estudo revela-se à medida que poderá contribuir para ampliar as discussões da temática no campo da formação de professores de Ciências e Biologia, professores estes que são, como lembram Silva e Santos (2011), tomados como referência para os estudantes quando o assunto é sexualidade. Ademais, dialogar essa temática nos cursos de formação é pertinente para que os futuros docentes se sintam preparados para abordar o tema sexualidade na escola, uma vez que essa temática está presente de diversas formas no ambiente escolar, como evidencia Louro (2014).

\section{Fundamentação Teórica}


Apesar de os documentos curriculares oficiais, tais como os PCN, sugerirem a abordagem da temática educação sexual de forma transversal, o debate sobre esse assunto sempre foi repleto de obstáculos, pois, como salienta Figueiró (2006 apud SILVA; SANTOS, 2011, p. 5) “"a temática] não é considerada uma questão prioritária na educação escolar [...] e quando [a abordagem] ocorre é por iniciativas isoladas de alguns professores". Porém existe uma dificuldade de inserção e discussão da temática no ambiente escolar, pois como destaca Bonfim (2009, p. 93), percebe-se "que ainda hoje impera um enfoque biologista e uma lacunar ausência de disciplinas sobre a sexualidade nas Licenciaturas".

\subsection{Formação de professores e a discussão sobre o tema sexualidade}

Muito embora seja de incontestável importância que os professores saibam lidar com as dúvidas e anseios dos estudantes quanto às questões relativas ao corpo e à sexualidade, ainda se percebe uma carência de abordagem a respeito destas questões nos currículos das licenciaturas. Como destaca Diniz e colaboradores (2015),

[...] no Brasil, a carga de responsabilidade para tratar dos temas relacionados à Educação Sexual em sala de aula é usualmente delegada aos professores de ciências e biologia, [...]. Entretanto, esses profissionais não possuem, em sua formação, a carga de conhecimentos necessária para discutir a sexualidade com seus alunos fora do discurso médico-biológico (DINIZ; CIRINO; HEREDERO, 2015, p. 4).

Bonfim (2009) argumenta que é necessário

[...] que se forneça aos docentes, e a futuros docentes, o embasamento teórico necessário para a compreensão da sexualidade como uma construção cultural, histórica, política e social, além do preparo didático para trabalharem a temática na escola (BONFIM, 2009, p. 7).

Considerando a necessidade de superar uma tendência biologicista de abordagem da sexualidade humana nas escolas, Santos e Silva (2011) reforçam que,

[...] se fazem necessárias mudanças na formação dos profissionais da educação, visto que os mesmos ainda se encontram despreparados diante de tal assunto. É necessária uma formação voltada para o sentido amplo da sexualidade, de forma a abranger todas as questões, extrapolando as influências do contexto cultural e biológico (SANTOS; SILVA, 2011, p. 5).

Dessa maneira, destacamos que é imprescindível inserir um debate amplo acerca da temática sexualidade nos cursos de formação de professores, pois possibilitará aos 




Revista Brasileira de Educação em

Ciências e Educação Matemática

DOI:https://doi.org/10.33238/ReBECEM.2020.v.4.n.4.25592

futuros docentes, em especial aos professores de Ciências e Biologia, o preparo necessário ao desenvolvimento de uma prática pedagógica que estimule a equidade em uma sociedade plural e democrática.

\subsection{Identidade nos Estudos Culturais}

Nesse trabalho pretende-se discutir sobre as identidades sexuais e de gênero. Para tanto, baseamo-nos nos estudos da identidade a partir da perspectiva dos Estudos Culturais. Os Estudos Culturais, segundo Escosteguy (1998, p. 34), "não configuram uma 'disciplina', mas uma área onde diferentes disciplinas interatuam, visando ao estudo de aspectos culturais da sociedade”. Moresco e Ribeiro (2015, p. 171) destacam que:

[...] os Estudos Culturais buscam compreender, nas sociedades industriais contemporâneas e em suas inter-relações de poder, a atuação da cultura nas mais diversas áreas temáticas: gênero, feminismo, identidades nacionais e culturais, políticas de identidade, pós-colonialismo, cultura popular, discurso, textos e textualidades, meios de comunicação de massa, pós-modernidade, multiculturalismo e globalização, entre outros (MORESCO; RIBEIRO, 2015, p. 171).

Tratando a respeito de identidade na perspectiva dos Estudos Culturais, entendese que ela está conectada de forma intrínseca com a diferença. Tomaz Tadeu da Silva (2000, p. 74) apresenta essa perspectiva evidenciando que:

[...] é fácil compreender, entretanto, que identidade e diferença estão em uma relação de estreita dependência. A forma afirmativa como expressamos a identidade tende a esconder essa relação. Quando digo 'sou brasileiro' parece que estou fazendo referência a uma identidade que se esgota em si mesma. 'Sou brasileiro' - ponto. Entretanto, eu só preciso fazer essa afirmação porque existem outros seres humanos que não são brasileiros (SILVA, 2000, p. 74).

Desse modo, uma pessoa somente se identifica com algo porque sabe da existência do diferente, com o qual ela não se identifica. Silva (2000) continua dizendo que por trás da afirmação "sou brasileiro", existe uma extensa cadeia de expressões de diferenças. Isto é, ao afirmar "sou brasileiro" está subentendido que "não sou argentino", "não sou japonês" e assim por diante.

Em relação aos processos de identidade e de diferença, Silva (2000) menciona que onde eles estão presentes, há a chamada diferenciação, que se caracteriza como sendo a maneira "central pela qual a identidade e a diferença são produzidas" (SILVA, 2000. p. 81). O autor ainda enfatiza que o estabelecimento da identidade e a marcação da diferença implicam no procedimento de “incluir/excluir ('estes pertencem, aqueles não'); demarcar 
DOI:https://doi.org/10.33238/ReBECEM.2020.v.4.n.4.25592

fronteiras ('nós' e 'eles'); classificar ('bons e maus'; 'puros e impuros'; 'desenvolvidos e primitivos'; 'racionais e irracionais'); normalizar ('nós somos normais; eles são anormais')" (SILVA, 2000, p. 81).

Nessa maneira de afirmar a identidade, de certo modo, ocorre a demarcação de "fronteiras", isto é, cria-se distinção entre as pessoas. Silva (2000, p. 81) menciona que essa distinção da identidade “está sempre ligada a uma forte separação entre 'nós' e "eles"”. E ao separar a sociedade dessa forma acontece o sistema de classificação social em que é estabelecida uma normalização de certa identidade. Tomaz Tadeu compreende a normalização como sendo

[...] um dos processos mais sutis pelos quais o poder se manifesta no campo da identidade e da diferença. Normalizar significa eleger - arbitrariamente - uma identidade específica como o parâmetro em relação ao qual as outras identidades são avaliadas e hierarquizadas. Normalizar significa atribuir a essa identidade todas as características positivas possíveis, em relação às quais as outras identidades só podem ser avaliadas de forma negativa. (SILVA, 2000, p. 83).

Portanto, a normalização é um processo que rotula como normal uma determinada identidade colocando-a como "fixa" e as demais sendo reconhecidas como desviantes ou anormais. Essa normalização de identidades se dá no bojo das relações sociais, por isso são carregadas de valores e interesses em constante disputa. Stuart Hall (2006) destaca que a discussão a respeito da identidade vem crescendo na chamada pós-modernidade, de tal forma que a sociedade está passando por um processo que ele intitula como "crise de identidade", quando os padrões de "normalidade" começam a ser questionados.

[...] a questão da identidade está sendo extensamente discutida na teoria social. As velhas identidades, que por tanto tempo estabilizaram o mundo social, estão em declínio, fazendo surgir novas identidades e fragmentando o indivíduo moderno. A crise de identidade é vista como parte de um processo mais amplo de mudança, que está deslocando as estruturas e processos centrais das sociedades modernas e abalando os quadros de referência que davam aos indivíduos uma ancoragem estável no mundo social (HALL, 2006, p. 7).

Para Hall, as identidades estão em colapso, pois o que era considerado socialmente "normal" em relação à classe, gênero, sexualidade, raça/etnia, construtos solidamente construídos na e pela Modernidade, estão passando por transformações que vem mudando as identidades das pessoas e abalando o pensamento delas em relação a si próprias. Para Hall, essa "perda de um 'sentido de si' pode constituir a chamada crise de identidade" (HALL, 2006, p. 9). Mercer (1990 apud HALL, 2006) ressalta que a crise identitária se dá quando identidades com suposições fixas, coerentes e estáveis começam a ser questionadas e ser rodeada de incertezas. Portanto, na perspectiva dos Estudos Culturais, 


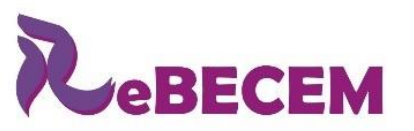

Revista Brasileira de Educação em

Ciências e Educação Matemática

DOI:https://doi.org/10.33238/ReBECEM.2020.v.4.n.4.25592

de acordo com Louro (2014), compreende-se que os sujeitos têm identidades plurais/múltiplas e essas identidades se transformam e não são fixas ou permanentes.

\subsection{Identidades de gênero}

De acordo com Louro (2014), o debate a respeito do conceito de gênero teve início por volta da década de 1960 dentro do movimento feminista. O movimento, além das preocupações políticas e sociais, se voltou na época para a construção de teorizações dentro das quais surgiu então a discussão sobre gênero.

Gênero é entendido como constituinte da identidade dos sujeitos (LOURO, 2014). Para a autora, "os sujeitos se identificam, social e historicamente, como masculinos e femininos e assim constroem suas identidades de gênero" (LOURO, 2014, p. 30). Ou seja, gênero diz respeito a uma percepção íntima da pessoa quanto à forma com o qual ela se reconhece. Antes da expansão do debate na área do gênero, vinculava-se a genitália com a qual o sujeito tinha nascido com o gênero que a pessoa "deveria se reconhecer". Nesse processo de imposição do gênero, que ainda hoje acontece, ocorre a construção dos chamados papéis masculinos e femininos. Guacira Louro entende esses papéis como “padrões ou regras arbitrárias que uma sociedade estabelece para seus membros e que definem seus comportamentos, suas roupas, seus modos de se relacionar ou de se portar [...]” (LOURO, 2014, p. 28).

Portanto, pode-se perceber que gênero é algo construído socialmente e que é designado às pessoas no momento do seu nascimento. Porém, essa percepção vem mudando a partir do entendimento de que gênero vai além dos papéis sociais designados a homens e mulheres. Simone de Beauvoir (1967, p. 9) proclama que "ninguém nasce mulher: torna-se mulher”. Isto é, a identificação quanto a ser ou não mulher é construída ao longo da vida, e não é definida pela genitália. No Brasil, atualmente, são reconhecidos dois gêneros: masculino e feminino. Porém, em outros países há o reconhecimento de outros gêneros. A título de exemplo, citamos as chamadas hijras ${ }^{5}$, na Índia. Esse reconhecimento das hijras como um terceiro gênero reforça que esta é uma construção social e que há múltiplas formas de se reconhecer.

\footnotetext{
${ }^{5}$ Reconhecido como terceiro sexo na Índia, hijras são pessoas nascidas do sexo masculino que se vestem e portam-se como mulheres, seriam as pessoas transexuais da Índia. Na tradição hindu, as hijras tem a capacidade de abençoar e amaldiçoar (CUNHA, 2015).
} 
DOI:https://doi.org/10.33238/ReBECEM.2020.v.4.n.4.25592

Em relação à discussão sobre gênero é necessário compreender algumas

nomenclaturas referentes às identidades, tais como: cisgênero, transgênero (transexual e travesti). No quadro abaixo é apresentada uma tentativa de explicação.

\begin{tabular}{|c|c|}
\hline \multirow{3}{*}{ Cisgênero } & $\begin{array}{l}\text { Cis (do latim: do mesmo lado) são pessoas que se identificam com o gênero que foi designado a elas } \\
\text { ao nascer. }\end{array}$ \\
\hline & $\begin{array}{l}\text { Homem Cis: pessoa que nasceu com pênis e foi registrada com o gênero masculino e que se } \\
\text { reconhece com esse gênero. }\end{array}$ \\
\hline & $\begin{array}{l}\text { Mulher Cis: pessoa que nasceu com vagina e foi registrada com o gênero feminino e que se } \\
\text { reconhece com esse gênero. }\end{array}$ \\
\hline \multirow{4}{*}{ Transgênero } & $\begin{array}{l}\text { Trans (do latim: para além de) são pessoas que não se identificam com o gênero que lhes foi } \\
\text { designado ao nascer. Apesar de não se reconhecerem com o gênero atribuído a elas no ato do } \\
\text { nascimento, essas pessoas não necessariamente realizam modificação no corpo através de } \\
\text { hormonização e cirurgia. }\end{array}$ \\
\hline & $\begin{array}{l}\text { Homem Transexual: pessoa que nasceu com vagina e foi registrada com o gênero feminino, porém } \\
\text { não se reconhece como mulher e sim como homem. Em alguns casos, a pessoa realiza modificação } \\
\text { no corpo através de homonização e cirurgia. }\end{array}$ \\
\hline & $\begin{array}{l}\text { Mulher Transexual: pessoa que nasceu com pênis e foi registrada com o gênero masculino, porém } \\
\text { não se reconhece como homem e sim como mulher. Em alguns casos, a pessoa realiza modificação } \\
\text { no corpo através de homonização e cirurgia. }\end{array}$ \\
\hline & $\begin{array}{l}\text { Travesti: pessoas nascidas com pênis e foram registradas com o gênero masculino, porém não se } \\
\text { reconhecem como homens. Essas pessoas se vestem como a sociedade espera que uma mulher se } \\
\text { vista. Esta é entendida como uma identidade autônoma, isto é, não são homens nem mulheres e sim, } \\
\text { travestis. Em alguns casos, a pessoa realiza modificação no corpo através de homonização e cirurgia. }\end{array}$ \\
\hline
\end{tabular}

Quadro 1. Identidades de gênero: cisgênero, transgênero (transexual e travesti)

Fonte: Extraído e adaptado de Jesus (2012, p. 15)

As identidades de gênero são comumente confundidas com as identidades sexuais. Enquanto as identidades de gênero tratam do modo como o indivíduo se reconhece socialmente, as identidades sexuais referem-se ao modo como ele se relaciona com seus desejos sexuais. Sobre isso trata o próximo tópico.

\subsection{Identidades sexuais}

Segundo Louro (2014), identidade sexual diz respeito às formas pelas quais a pessoa vive a sua sexualidade "com parceiros (as) do mesmo sexo, do sexo oposto, de ambos os sexos ou sem parceiros (as)" (LOURO, 2014, p. 30). Ou seja, é a maneira como a pessoa se identifica em relação aos seus desejos sexuais, isto é, por quem sente atração.

Assim como para as identidades de gênero, na Modernidade há também para as identidades sexuais uma identidade considerada normal e socialmente aceitável: a heterossexualidade. As pessoas que fogem do padrão são vistas supostamente como “desviantes". Esta visão ainda é prevalente, porém com o aumento do debate em relação à temática começou-se a compreender que as identidades sexuais são construídas e 
DOI:https://doi.org/10.33238/ReBECEM.2020.v.4.n.4.25592

desconstruídas ao longo da vida da pessoa. Como afirma Louro (2014, p. 31) "as identidades estão sempre se construindo, elas são instáveis e, portanto, passíveis de transformação". Isto é, tanto as identidades de gênero quanto as sexuais vêm sendo compreendidas como dinâmicas e não acabadas ou fixas.

Devido ao processo de normalização social, sempre se elegeu a identidade heterossexual como natural e normal, e as demais identidades como anormais. Neste sentido, as estruturas sociais operam ações para que as pessoas não se desviem do padrão "natural", isto é, heterossexual. Guacira Louro (2014) contesta essa normalização como algo naturalmente dado, entendendo-a como um processo arbitrário, forjado nas relações de poder. A escola não escapa destes processos, ainda que se negue a discuti-los. Conforme aponta Louro (2014),

[...] se a identidade heterossexual fosse, efetivamente, natural (e, em contrapartida, a identidade homossexual fosse ilegítima, artificial, não natural), por que haveria a necessidade de tanto empenho para garanti-la? Por que 'vigiar' para que os alunos e alunas não 'resvalem' para uma identidade 'desviante'? (p. 85).

Portanto, é possível perceber que as identidades sexuais são todas construídas ao longo da vida de uma pessoa e que todas as formas de sexualidade são legítimas, o que aponta um desafio para que nós, professores, "possamos compreender melhor o fato de que diferentes sujeitos, homens e mulheres, vivam de vários modos seus prazeres e desejos" (LOURO, 2014, p. 85).

Quanto à questão das identidades sexuais, também é indispensável entender as mais frequentes nomenclaturas referentes às identidades encontradas, tais como: assexual, bissexual, heterossexual e homossexual. No quadro abaixo é apresentada uma tentativa de elucidação.

\begin{tabular}{|c|l|}
\hline Assexual & $\begin{array}{l}\text { Pessoa que não se sente atraída afetivamente e/ou sexualmente por pessoas de qualquer } \\
\text { gênero. }\end{array}$ \\
\hline Bissexual & $\begin{array}{l}\text { Pessoa que se sente atraída afetivo-sexualmente por pessoas de ambos os gêneros, } \\
\text { masculino e feminino. }\end{array}$ \\
\hline Heterossexual & $\begin{array}{l}\text { Pessoa que se sente atraída afetivo-sexualmente por pessoas do gênero oposto daquele } \\
\text { com o qual se identifica. }\end{array}$ \\
\hline Homossexual & $\begin{array}{l}\text { Pessoa que se sente atraída afetivo-sexualmente por pessoas de gênero igual àquele } \\
\text { com o qual se identifica. }\end{array}$ \\
\hline
\end{tabular}

Quadro 2. Identidades sexuais

Fonte: Extraído e adaptado de Jesus (2012, p. 16).

Conforme vimos, há diferenças entre as identidades de gênero e as identidades sexuais. Entender essas diferenças nos parece fundamental para o desenvolvimento da prática pedagógica dos professores, ao lidarem com a temática sexualidade. 


\section{Metodologia}

\subsection{Abordagem da pesquisa}

Este estudo trata de uma pesquisa no campo do ensino de Ciências utilizando uma abordagem qualitativa. Esse tipo de pesquisa é "um processo de reflexão e análise da realidade através da utilização de métodos e técnicas para compreensão detalhada do objeto de estudo em seu contexto histórico e/ou segundo sua estruturação" (OLIVEIRA, 2008, p. 41). Além do mais, essa modalidade de pesquisa, como salienta Castro et al. (2011, p. 6),

[...] tem como característica a relação direta com o objeto de estudo, quando permite dar voz aos sujeitos pesquisados, sem a pretensão de produzir generalizações, uma vez que seu foco é o entendimento profundo de uma dada realidade específica. (CASTRO et al., 2011, p. 6).

Com a intenção de obter familiaridade com o problema estudado, adotou-se nesse trabalho o método de pesquisa exploratória, cujo objetivo é "proporcionar, através da imersão do pesquisador no contexto, uma visão geral e não enviesada do problema considerado, e contribuir para a focalização das questões e a identificação de informantes e outras fontes de dados" (MAZZOTTI, 1991, p. 58).

\subsection{Cenário e sujeitos da pesquisa}

Tendo em vista a proposta do trabalho, o cenário escolhido para a pesquisa foi o curso de Licenciatura em Ciências Biológicas de uma universidade federal mineira, e teve como sujeitos os estudantes que estavam matriculados na disciplina "Estágio Supervisionado em Ensino de Biologia”, ofertada no primeiro semestre de 2019. A justificativa para escolha dos sujeitos se deu porque esse estágio se encontra no final do curso e os estagiários já teriam passado por dois estágios e vivenciado de forma mais próxima à realidade escolar. Com isso, entende-se que conhecer as percepções desses sujeitos sobre sua formação é pertinente, pois supõe-se que sejam formandos ou estejam prestes a se formar. Na pesquisa, participaram 11 pessoas, sendo oito mulheres e três homens e todos cursavam o oitavo período do curso. 


\subsection{Instrumentos de coleta de dados}

A técnica utilizada para coleta de dados foi o Grupo Focal (GF). Segundo Powell e Single (1996, p. 449 apud GATTI, 2005 p. 7), a técnica se caracteriza por "um conjunto de pessoas selecionadas e reunidas por pesquisadores para discutir e comentar um tema, que é o objeto de pesquisa, a partir de sua experiência pessoal". Essa técnica é bastante interessante, pois como salienta Morgan e Krueger (1993 apud GATTI, 2005 p. 7) “[...] permite fazer emergir uma multiplicidade de pontos de vista e processos emocionais, pelo próprio contexto de interação criado, permitindo a captação de significados que, com outros meios, poderiam ser difíceis de se manifestar".

Entendendo que é uma técnica de diálogo em grupo, pretendeu-se coletar as experiências e as percepções individuais e do coletivo acerca da temática em tela. Entendemos ser adequado adotar o GF, pois como ressalta Gatti (2005)

[...] a técnica é muito útil quando se está interessado em compreender as diferenças existentes em perspectivas, ideias, sentimentos, representações, valores e comportamentos de grupos diferenciados de pessoas, bem como compreender os fatores que os influenciam, as motivações que subsidiam as opções, os porquês de determinados posicionamentos (p. 14).

Para a realização de um grupo focal é necessária a presença de um moderador e de um observador de fluxo e clima. O moderador se encarrega de "manter produtiva a discussão e garantir que todos os participantes exponham suas ideias, impedir a dispersão da questão em foco e evitar a monopolização da discussão por um dos participantes" (PIZZOL, 2003 apud GATTI, 2005, p. 34). Por outro lado, o observador de fluxo e clima é encarregado de captar as informações não verbais dos participantes durante o desenvolvimento do grupo focal (BORGES; SANTOS, 2005).

Para a condução do GF foi elaborado um roteiro semiestruturado que serviu de base para conduzir o diálogo, pois continha os principais pontos que seriam abordados. Esse roteiro foi usado pela moderadora, porém por ser semiestruturado, permitiu que fossem feitas adaptações à medida que surgiam questões inesperadas. Para o registro das informações optou-se pela gravação em áudio. Salienta-se que foram tomados os cuidados éticos necessários para a realização da pesquisa, tendo a mesma sido aprovada pelo Comitê de ética da instituição sob o número CAAE 03347318.4.0000.5108. Também foi previamente apresentado para os participantes do grupo focal o Termo de Consentimento Livre e Esclarecido (TCLE), o qual foi lido e assinado por todos. 


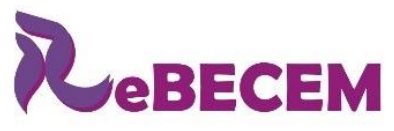

DOI:https://doi.org/10.33238/ReBECEM.2020.v.4.n.4.25592

Portanto, para o grupo focal, foi feito o convite prévio aos estudantes da disciplina "Estágio Supervisionado em Ensino de Biologia" para que pudessem participar e colaborar com a pesquisa. O encontro foi moderado pela professora da disciplina e teve duração de uma hora e 36 minutos. Inicialmente, a mediadora realizou a leitura do TCLE juntamente aos acadêmicos e os mesmos concordaram com a participação e gravação do diálogo. O mesmo foi transcrito na íntegra e analisado por meio da Análise Textual Discursiva (ATD).

\subsection{Instrumento para tratamento dos dados}

Para esta pesquisa foi utilizada a Análise Textual Discursiva (ATD) de Moraes e Galiazzi (2006) como instrumento metodológico de análise dos dados. A ATD é considerada "uma abordagem de análise de dados que transita entre duas formas consagradas de análise [...] que são a análise de conteúdo e a análise de discurso" (MORAES; GALIAZZI, 2006, p. 118). ATD consiste em três etapas de análise: unitarização, categorização e metatextos, que serão explicadas adiante.

A ATD se materializa em um conjunto documental chamado corpus. O corpus é formado por produções textuais, sendo que esses textos "podem tanto terem sido produzidos especialmente para a pesquisa, como podem ser documentos já existentes previamente" (MORAES, 2003). Neste trabalho, o corpus foi o texto transcrito do Grupo Focal, o qual produziu um acervo de informações que foram usadas na pesquisa.

Conforme salientado anteriormente, a ATD consiste em um processo de desconstrução do texto e sua unitarização. De acordo com Moraes e Galiazzi (2006, p. 118), na etapa de unitarização “os textos são separados em unidades de significado" e é preciso "interpretar e isolar ideias elementares de sentido sobre os temas investigados" (MORAES; GALIAZZI, 2006, p. 123).

Após a desconstrução e unitarização, inicia-se o processo de categorização das unidades construídas. A categorização é um processo em que há comparação contínua entre as unidades estabelecidas no seguimento inicial da análise, formando conjuntos de elementos semelhantes (MORAES, 2003). As categorias, segundo o autor, devem ser válidas e homogêneas. São consideradas válidas quando as informações contidas nas categorias são capazes de "melhorar a compreensão dos fenômenos investigados" e as categorias precisam ser homogêneas, pois "precisam ser construídas a partir de um mesmo princípio, de um mesmo contínuo conceitual” (MORAES, 2003, p. 199). Além 


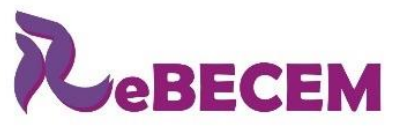

DOI:https://doi.org/10.33238/ReBECEM.2020.v.4.n.4.25592

\section{Revista Brasileira de Educação em \\ Ciências e Educação Matemática \\ ISSN 2594-9179}

disso, as categorias podem ser pré-estabelecidas ou emergir ao longo da pesquisa. Neste caso específico, temos quatro categorias pré-estabelecidas (a priori) conforme veremos na discussão dos resultados.

Baseado na unitarização e categorização do corpus é que se constrói a estrutura básica do metatexto. Os metatextos, de acordo com Moraes (2003, p. 202), "são constituídos de descrição e interpretação, representando o conjunto de compreensão e teorização dos fenômenos investigados".

\section{Resultados e discussão}

Na ATD, após a unitarização dos dados, os mesmos são separados em categorias e subcategorias de significados semelhantes. Como citado anteriormente, o corpus da presente pesquisa foi dividido em quatro categorias a priori, e em 16 subcategorias sendo duas a priori e 14 emergentes, explicitadas no quadro 3.

\begin{tabular}{|c|c|c|}
\hline $\begin{array}{c}\text { Categorias pré-estabelecidas ( } a \\
\text { priori) }\end{array}$ & $\begin{array}{c}\text { Subcategorias } a \\
\text { priori }\end{array}$ & $\begin{array}{c}\text { Subcategorias emergentes (a } \\
\text { posteriori) }\end{array}$ \\
\hline \multirow{2}{*}{$\begin{array}{l}\text { 1. Diferenciação de identidade de } \\
\text { gênero e identidade sexual }\end{array}$} & Identidade de Gênero & \multirow{2}{*}{ Representação identitária } \\
\hline & Identidade Sexual & \\
\hline \multirow{5}{*}{$\begin{array}{l}\text { 2. Atuação no estágio/Vivência na } \\
\text { escola }\end{array}$} & \multirow{5}{*}{ (2) } & Carência na abordagem \\
\hline & & Ausência de reação \\
\hline & & Tentativa de diálogo \\
\hline & & Insegurança \\
\hline & & $\begin{array}{l}\text { Importância de educação sobre } \\
\text { sexualidade }\end{array}$ \\
\hline \multirow{4}{*}{$\begin{array}{l}\text { 3. Formação no curso/na } \\
\text { universidade }\end{array}$} & \multirow{4}{*}{-} & Disciplina \\
\hline & & $\begin{array}{l}\text { Programas Governamentais } \\
\text { (PET/PIBID) }\end{array}$ \\
\hline & & História pessoal \\
\hline & & Demandas para formação (Sugestões) \\
\hline \multirow{4}{*}{ 4. Situações simuladas } & \multirow{4}{*}{ - } & Relação com a idade \\
\hline & & Naturalizar o assunto \\
\hline & & Dificuldades de abordagem \\
\hline & & Trabalhar o respeito \\
\hline
\end{tabular}

Quadro 3. Categoria a priori e subcategorias a priori e emergentes do corpus do grupo focal Fonte: Elaborado pelos autores.

As categorias pré-estabelecidas ou a priori são as categorias que estabelecemos previamente para a realização do GF, enquanto as subcategorias emergentes são aquelas 


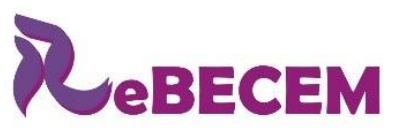

Revista Brasileira de Educação em

Ciências e Educação Matemática

DOI:https://doi.org/10.33238/ReBECEM.2020.v.4.n.4.25592

que surgiram de maneira inesperada durante o desenvolvimento do GF. A seguir, apresentamos a análise das categorias em forma de metatextos. Ressalta-se que as subcategorias emergentes estarão sublinhadas ao longo do texto.

\subsection{Diferenciação de Identidade de Gênero e Identidade Sexual}

A primeira categoria a priori de análise a partir da ATD diz respeito à diferenciação das identidades de gênero e sexuais. Os formandos foram questionados no grupo focal a respeito das diferenças entre os termos identidade de gênero e identidade sexual, que entendemos como uma subcategoria que foi pré-estabelecida (a priori). A maioria deles demonstrou dificuldades em diferenciar estas identidades, conforme vemos nos fragmentos de fala a seguir: Estudante 1 - "Vira uma bagunça na minha cabeça essa coisa de identidade de gênero e
tudo, ainda mais com relação à homossexualidade, né? [...] Então, pra mim isso não fica
muito claro, sabe, na minha cabeça isso é muito bagunçado essa coisa de identidade de
gênero, como eu devo tratar isso, as terminologias mesmo para tratar".

Estudante 2 - "Eu também não sei”.

Estudante 3 - "[...] eu tenho as mesmas dificuldades que as meninas falaram de compreender esses termos de hoje em dia".

Como relatado, podemos perceber que os participantes citados demonstram-se confusos em relação às identidades de gênero e sexuais, porém todos os demais estudantes também relataram dificuldades com a temática. Retomando aos conceitos que foram trazidos no referencial teórico, Louro (2014) acentua que as identidades de gênero se referem às formas como os sujeitos se identificam social e historicamente como masculinos, femininos, dentre outros. Enquanto as identidades sexuais são as formas como os sujeitos vivem sua sexualidade com parceiros do mesmo gênero, ou do gênero oposto, com ambos ou nenhum dos gêneros. Porém, na própria sigla $\mathrm{LGBT}^{6}$ as identidades estão misturadas, pois incluem as identidades sexuais (Lésbicas, Gays, Bissexuais) e também identidades de gênero (Travestis e Transexuais), portanto é natural que a confusão exista em função da transitoriedade das identidades de gênero e sexuais.

\footnotetext{
${ }^{6}$ LGBT: sigla para Lésbicas, Gays, Bissexuais, Travestis e Transexuais. Desde o início do movimento até a atualidade houve discussões em torno da sigla que sempre predominou LGBT. Mais recentemente foram adicionadas a ela as letras Q, I, A e o símbolo “+”, que significa queers, intersexuais, assexuais e o símbolo de mais é para incluir pessoas que não se sintam representadas por nenhuma das outras sete letras, portanto atualmente a sigla é LGBTQIA+ (BORTOLETTO, 2019).
} 
Sobre esta transitoriedade, Louro (2014) completa que as identidades estão em constante construção e ressignificação e não são fixas e acabadas. A autora salienta que,

os sujeitos vão se construindo como masculinos ou femininos, arranjando e desarranjando seus lugares sociais, suas disposições, suas formas de ser e de estar no mundo. Essas construções e esses arranjos são sempre transitórios, transformando-se não apenas ao longo do tempo, historicamente, como também transformando-se na articulação com as histórias pessoais, as identidades sexuais, étnicas, de raça, de classe (LOURO, 2014, p. 28).

Por essas identidades estarem continuamente em transformação, é natural que as pessoas se sintam "desatualizadas" em relação às "definições", como foi relatado pelos formandos:

Estudante 3- "[...] antes era LGBT e agora tem não sei mais quantas letras no meio que a gente nem sabe mais".

Estudante 1- "[...] como a Estudante 3 falou, ontem era LGBT, hoje já tem um tanto de letra no meio, então pode ser que já tenha mudado e eu estou bem mais atrás".

Por esse motivo, os formandos se sentem inseguros em falar sobre a temática, uma vez que as identidades são fluidas e continuamente estarão em um processo de reconstrução. No entanto, como futuros professores é de extrema importância que se esforcem para acompanhar as mudanças e busquem conhecimentos a respeito da temática, de modo a terem esclarecimento suficiente para dialogarem com seus estudantes.

Ainda durante o GF, emergiu dos participantes a preocupação com a forma de se referir às pessoas pertencentes à comunidade LGBTQIA+. Eles relatam serem cuidadosos para que os tratem de maneira respeitosa e não ofensiva.

Estudante 1 - “[...] A gente tem que saber como vai tratar, porque às vezes o pessoal mesmo não gosta, quem é homossexual... Às vezes eu falo assim: "você é gay", aí a pessoa fala "não, não sou gay" ou "não gosto que usa esse termo para se referir a mim"”."

Estudante 4 - "[...] acontecia situações que eu tratava uma pessoa de uma maneira que eu não queria, eu era grossa, eu era desrespeitosa com uma pessoa trans, ou gay, ou lésbica, ou qualquer outro gênero, e eu me senti mal por isso, toda vez que eu via que a pessoa ficava incomodada".

Ou seja, com esses relatos, é perceptível a preocupação com a maneira que irão tratar uma pessoa da comunidade LGBTQIA+, buscando serem cuidadosos na fala. Portanto, entendemos isso como uma subcategoria emergente que chamamos de representação identitária. Silva (2000) destaca que a linguagem é um importante mecanismo da identidade, tendo em vista que ela abarca de forma geral um conjunto de significações, isto é, uma forma de definição daquilo que é, distinguindo-o daquilo que não é. Essa distinção se dá por meio de processos de diferenciação. Portanto, ao nomear 
DOI:https://doi.org/10.33238/ReBECEM.2020.v.4.n.4.25592

as identidades sexuais e de gênero, por exemplo, lésbica, transexual, percebe- se uma busca por representação e por reconhecimento. Na fala da Estudante 1, citada anteriormente, nota-se sua preocupação com a maneira de tratamento, isto é, em não se referir a uma pessoa por meio de um signo que ela não sinta representada identitariamente. Nesse sentido, Silva (2000, p. 76) ressalta que,

[...] dizer, por sua vez, que identidade e diferença são o resultado de atos de criação linguística significa dizer que elas são criadas por meio de atos de linguagem. [...] com frequência esquecemos que a identidade e a diferença têm que ser nomeadas. (SILVA, 2000, p. 76).

Por esse motivo é tão importante que os licenciandos dominem os signos referentes às diferentes formas identitárias.

\subsection{Atuação no estágio/ Vivência na escola}

A segunda categoria pré-estabelecida ou a priori de análise, a partir da ATD, refere-se às experiências de estágios e vivências na escola. De acordo com Louro (2000 apud OLIVEIRA; MENEZES FARIA, 2016, p. 511), "se a escola é uma instituição social ela está, obviamente, envolvida com as formas culturais e sociais de vivermos e constituirmos nossas identidades de gênero e nossas identidades sexuais". Aqui recuperamos a perspectiva de Tomaz Tadeu da Silva (2000, p. 74) que afirma que “identidade e diferença estão em uma relação de estreita dependência”. Isto é, o ambiente escolar tem grande influência na construção de nossas identidades, pois nele é possível se informar, conhecer e se relacionar com o diferente. Ao serem questionados no GF a respeito das experiências que tiveram com a temática sexualidade durante o estágio ou em outro contato com a escola, os formandos pontuaram, por exemplo, a carência na abordagem desse assunto pela escola. Esta é uma subcategoria que emergiu na fala dos formandos, como exemplificado nos trechos a seguir:

Estudante 3 - "no Estágio I, se não me engano era no $8^{\circ}$ ano, e a professora estava dando aula sobre métodos contraceptivos, aí a aula acabou e eu senti falta de falar da parte dos métodos para pessoas homossexuais, se precisa ou não".

Estudante 1 - "quando o tema sexualidade era abordado na escola foi sobre doenças sexualmente transmissíveis, igual a Estudante 3 falou, era mais voltada para o lado hétero e ninguém nunca trabalhou sobre as identidades de gênero botando (sic) essa questão de DST (sic) para pessoas que são homossexuais ou trans".

Diante disso, podemos perceber que nas escolas, ainda hoje, é incipiente o debate da temática sexualidade para além de uma visão biologicista. Quando abordam o assunto 
DOI:https://doi.org/10.33238/ReBECEM.2020.v.4.n.4.25592

numa perspectiva meramente biológica, conforme citado na fala acima - discussão sobre DST (sic) e métodos contraceptivos - ainda assim os professores focalizam as aulas para as pessoas cisgêneros e heterossexuais, ignorando completamente outras identidades de gênero e sexuais. Ou seja, não abordar o assunto sugere a negação da existência de pessoas LGBTQIA+. Louro (2014) alerta que,

[...] ao não se falar a respeito deles e delas, talvez se pretenda 'eliminá-los/as', ou, pelo menos, se pretenda evitar que os alunos e as alunas 'normais' os/as conheçam e possam desejá-los/ as. Aqui o silenciamento - a ausência da fala aparece como uma espécie de garantia da 'norma' (p. 71).

A autora ainda afirma que,

[...] a negação dos/as homossexuais no espaço legitimado da sala de aula acaba por confiná-los às 'gozações' e aos 'insultos' dos recreios e dos jogos, fazendo com que, deste modo, jovens gays e lésbicas só possam se reconhecer como desviantes, indesejados ou ridículos (LOURO, 2014, p. 72).

Alinhados a essa ideia, que a negação desses sujeitos pela escola pode colocá-los como motivos de gozação, durante o GF, foram relatados casos de bullying sofridos por alguns estudantes. A seguir, tem-se o relato de uma situação presenciada por um dos formandos:

Estudante 8 - "Eu sentei no fundo da sala e tinha um aluno ao meu lado que aparentava ser homossexual e estava conversando só com um grupo de garotas. Do outro lado da sala tinha um grupo de meninos que estavam zoando ele, falando: "um tanto de mulher bonita aqui na escola e vai gostar justo de homem”? [...] E eu fiquei calado, achei sem graça, porque o rapaz ficou sem graça".

Nota-se que perante essa situação, o acadêmico percebeu a fala discriminatória, porém não interviu. A ausência de reação do formando foi considerada uma subcategoria emergente, ou seja, esse comportamento coloca-o como conivente com a situação. Seria de extrema importância cercear esse tipo de fala preconceituosa, no entanto, o formando não se manifestou. Verifica-se que essa e outras situações são bastante recorrentes no ambiente escolar, como evidencia Junqueira (2009, p. 15): “a escola configura-se um lugar de opressão, discriminação e preconceitos, no qual e em torno do qual existe um preocupante quadro de violência a que estão submetidos milhões de jovens e adultos LGBT". O autor ainda acrescenta que esses sujeitos enfrentam, durante a vivência escolar, diversos obstáculos para se envolverem nas atividades pedagógicas e para terem suas identidades minimamente respeitadas (JUNQUEIRA, 2009).

Ainda sobre as vivências na escola, outros formandos destacaram o surgimento de ações discriminatórias, porém houve uma tentativa de diálogo dos acadêmicos com os 
DOI:https://doi.org/10.33238/ReBECEM.2020.v.4.n.4.25592

educandos para tentar informá-los. Esta foi considerada uma subcategoria emergente, como veremos nos fragmentos de falas a seguir:

Estudante 1 - "uns alunos falaram comigo assim: "ah dona, agora a gente não pode falar daquele seu amigo lá da faculdade [...] porque ele é gay". Ai eu falei: "vocês teriam coragem de falar alguma coisa com ele só porque ele é gay? Vocês acham que tem problema nisso?"

Estudante 7 - "Eu não vivenciei nada nesse sentido assim não, mas nosso colega (nome da pessoa), que é da Residência Pedagógica, ele vivenciou isso no $7^{\circ}$ ano, isso de meninos ficarem mexendo com o outro que parecia ser homossexual. E aí ele parou tudo e chamou todos para conversar sobre a questão e começaram a debater".

Com esses dois relatos, é perceptível que houve a tentativa de diálogo para tentar problematizar situações preconceituosas vivenciadas no ambiente escolar, porém nem todos os participantes se sentem aptos para realizar essa abordagem, como citou uma acadêmica:

Estudante 4 - "no estágio, a gente depara com situações que a gente precisa intervir e às vezes a gente não tem como, ou não está completamente preparado, ou não se sente à vontade ou não sente que fazer aquilo de uma forma crua seja a forma certa".

A sensação de despreparo relatada é algo corriqueiro entre os estudantes que participaram do GF. A insegurança foi considerada uma subcategoria emergente. Porém, conforme já assinalamos, há a necessidade de intervir nos momentos em que emergem situações preconceituosas, pois como aponta Arruda (2009),

[...] é nessa etapa da vida dos educandos que ocorre o turbilhão das transformações e a carência de informações é grande, assim como o despreparo dos professores perante às dúvidas, não somente nas questões biológicas, mas principalmente nas questões sensuais e afetivas e é exatamente [desse despreparo] que os educandos não precisam (ARRUDA, 2009 apud DE OLIVEIRA; MENEZES FARIA 2016, p. 511).

Ainda durante o grupo focal, emergiu como subcategoria a importância da educação para a sexualidade nas escolas. Sobre isso os formandos expuseram que:

Estudante 2 - "é um assunto que a gente precisa tratar com os alunos, principalmente os alunos que estão entrando na puberdade, né? Eles têm um interesse muito grande em saber sobre isso".

Estudante 4 - "[...] acho que na escola isso devia ser tratado, porque ali, na adolescência, a gente está descobrindo tudo e os meninos precisam que alguém tente explicar pra ele".

A partir disso, podemos perceber que os acadêmicos reconhecem que a temática sexualidade é um assunto de relevância para abordar com os estudantes, uma vez que eles se encontram na faixa etária em que estão descobrindo a sua sexualidade e estão rodeados de dúvidas sobre o tema. Leão (2009, p. 249) destaca que, "a adolescência é também uma faixa etária que carece de cuidados, principalmente porque neste momento emerge com 


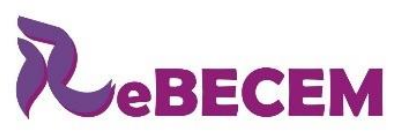

Revista Brasileira de Educação em

Ciências e Educação Matemática

DOI:https://doi.org/10.33238/ReBECEM.2020.v.4.n.4.25592

veemência a sexualidade". Os formandos ainda destacam que os professores devem se preocupar em informar os estudantes para sanar as dúvidas e colocam a escola como fonte fidedigna. A seguir, vemos trechos das falas:

Estudante 2- "se a gente não falar disso na escola, eles vão acabar tendo informação sobre isso em algum momento, e talvez essa informação pode ser equivocada e pode, sei lá, pode gerar consequências muito piores".

Estudante 4- "o mundo está cheio de informação, cheio... cheio... De informação certa, de informação errada e eu acho que hoje em dia a escola serve muito como um filtro disso. [...] A gente tem que se preocupar hoje em dia, como professores, em filtrar essa informação toda que está ali na cabeça do menino para não confundir ele".

Maistro (2006, p. 112), destaca que, "são os professores ou orientadores que se constituem interlocutores confiáveis para as questões da sexualidade". A relação cotidiana dos estudantes com seus professores pode trazer a confiança necessária para uma abordagem genuína e clara sobre suas dúvidas e anseios. No entanto, como já salientamos, para que os professores consigam sanar as dúvidas de seus estudantes é necessário que eles tenham conhecimento sobre a temática. A seguir, trataremos sobre as percepções dos formandos que participaram da pesquisa, sobre o preparo para lidar com esse assunto.

\subsection{Formação no curso/ na universidade}

A terceira categoria pré-estabelecida, analisada a partir da ATD, diz respeito à formação acadêmica, tanto no curso de Licenciatura de Ciências Biológicas quanto na universidade como um todo. Ao serem questionados com relação à formação que tiveram, os acadêmicos relatam que houve poucas oportunidades em que tiveram contato com a temática sexualidade, conforme evidenciaram no GF:

Estudante 1- "Até aqui na universidade, eu não tive uma disciplina que eu aprendesse isso".

Estudante 7- "Eu já ia falar isso, que a gente não teve isso na universidade".

Após a fala da Estudante 1, outra formanda concordou sobre a carência de abordagem da temática durante a formação. Foi notório em outros relatos dos acadêmicos que quando tiveram alguma discussão sobre o assunto, de maneira geral foram abordagens pontuais, ou seja, o debate ocorreu em algum trabalho para uma disciplina. Ainda segundo eles, quando ocorria a discussão sobre sexualidade, o tema priorizado eram as doenças sexualmente transmissíveis (DST) (sic), nada sendo mencionado acerca 


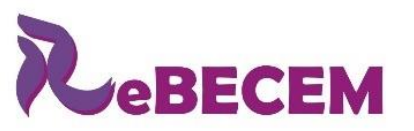

Revista Brasileira de Educação em

Ciências e Educação Matemática

DOI:https://doi.org/10.33238/ReBECEM.2020.v.4.n.4.25592

das identidades de gênero e sexuais. Gostaríamos de salientar que em sua fala, uma participante refere-se às Infecções Sexualmente Transmissíveis (IST) ainda pela denominação antiga, DST. Segundo o regimento estrutural do Ministério da Saúde, por meio do Decreto $\mathrm{n}^{\circ}$ 8.901/2016, houve atualização da nomenclatura DST para IST. A palavra 'doença' implica em sintomas visíveis no organismo do indivíduo. Já o termo ‘infecções' pode referir-se a períodos em que o indivíduo não apresenta sintomas ou à possiblidade do mesmo ficar por toda a vida assintomático, sendo preciso realizar exames laboratoriais para identificar a presença de um agente infeccioso. A referência feita à DST e não à IST evidencia novamente a ausência de discussão atualizada sobre sexualidade nas disciplinas do curso. Ao se referirem à abordagem da sexualidade nas disciplinas destacamos uma subcategoria emergente.

Alguns relataram também que tiveram contato com o tema através de oficinas que elaboraram em Programas Governamentais, como o Programa de Educação Tutorial (PET), o Programa Institucional de Bolsas de Iniciação à Docência (Pibid) e também em um evento acadêmico da própria universidade, ou à Semana de Integração (Sintegra). Neste caso, destacamos a subcategoria emergente Programas Governamentais. A seguir constam alguns relatos:

Estudante 4- "Eu lembro que quando eu fiz Laboratório (de ensino) II [...] e um dos grupos fizeram (sic) um trabalho sobre sexualidade, mas era muito isolado".

Estudante 1- "Eu fiz uma eletiva, que é inclusive da grade nova [...]. Foi uma repetição do que a gente já anda fazendo, que é essa coisa do transversalismo (sic) que é dar uma palestra sobre DST (sic) e pronto e acabou ali".

Estudante 2- "Eu fiz uma oficina, quando eu estava no Pibid, que era sobre sexualidade e a gente abordou sobre isso, sobre identidade de gênero [...] eu estudei naquela época só pra falar daquilo com os meninos, mas se perguntar hoje eu não lembro, não sei".

Estudante 5- "[...] em um trabalho no PET, que meu grupo ficou responsável por organizar, mas como tem muito tempo, acho que fiquei um pouco perdida".

Estudante 4- "Teve na Sintegra desse ano agora. Eu vi, não lembro exatamente o nome, mas teve abordando o assunto em forma de trabalhos".

Corroborando com a afirmação da falta de discussão no interior do curso, emergiu durante o GF que o conhecimento que alguns participantes têm, advém de vivências e buscas pessoais por informações. Essa também foi considerada uma subcategoria emergente que denominamos história pessoal. Veja os trechos de fala a seguir:

Estudante 4- "[...] eu, ultimamente, tenho tentado buscar informação sobre o assunto". 
DOI:https://doi.org/10.33238/ReBECEM.2020.v.4.n.4.25592

Estudante 1- "O que eu sei, eu aprendi a partir de conhecimento de mundo, de ver o pessoal falando sobre".

Essas falas sugerem que os estudantes não tiveram acesso a discussões a respeito das identidades de gênero e sexuais durante a formação acadêmica, pois eles aprenderam por conta própria acerca da temática. Bonfim (2009) salienta que nos cursos de Licenciatura em Ciências Biológicas há escassez de disciplinas que discutam sobre a sexualidade humana para além do enfoque biológico. Como relatado pelos participantes do GF, quando eles tiveram discussões sobre sexualidade durante a graduação, restringiam-se somente ao aspecto biológico, e não apresentavam reflexões sobre questões sociais referentes a identidades de gênero e sexuais. Felipe e Guizzo (2004 apud SILVA; SANTOS, 2011, p. 8), confirmam a escassez de oportunidades para tratar sobre a temática nos cursos superiores. Elas afirmam que:

[...] nos cursos de formação docente em nível universitário, raramente têm a oportunidade de discutir a respeito dessas questões [de sexualidade], uma vez que os currículos ainda não contemplam de forma abrangente tais temáticas. Dificilmente são oferecidas disciplinas que se dedicam especificamente aos assuntos, muitas vezes sendo este trabalho de forma tangencial (FELIPE; GUIZZO, 2004 apud SILVA; SANTOS, 2011, p. 8).

Ao questionar os formandos se eles achavam que estavam preparados para tratar da temática com seus futuros estudantes, os mesmos relataram que:

Estudante 4- "Não me sinto preparada para falar de sexo com um menino que nem teve matéria direito sobre aquilo".

Estudante 1- "A minha concepção é que a gente não está preparado para trabalhar sexualidade com o conhecimento que a gente tem aqui da universidade".

Estudante 6- "Eu tenho uma certa dificuldade de conversar sobre esses assuntos [...] porque eu acho bem delicado e eu não tenho muita preparação".

Em relação à sensação de despreparo, fazemos uma reflexão junto ao leitor sobre qual deveria ser a preparação adequada desses formandos, uma vez que no interior do curso não há discussões a respeito da sexualidade, sequer nas disciplinas biológicas. A Anatomia e Fisiologia Humana, disciplinas presentes no currículo do curso, restringemse em apresentar informações sobre a morfologia e o funcionamento do corpo humano, sem realizar debates sobre sexualidade. Relacionar, por exemplo, a função de algumas estruturas das regiões íntimas ao prazer sexual poderia ser um tema para debate. Teriam os órgãos sexuais unicamente uma "função" reprodutiva? Por que sentimos prazer em diferentes partes do corpo e de diferentes formas? Teria o prazer uma funcionalidade fisiológica? Ou será que o prazer não é "funcional"? Esses tipos de questionamentos 
DOI:https://doi.org/10.33238/ReBECEM.2020.v.4.n.4.25592

poderiam criar oportunidades de discutir inclusive sobre a diversidade sexual, já que este debate no curso é essencial para a formação de profissionais que atuarão nas escolas, onde são recorrentes as dúvidas e tabus entre os estudantes.

Os formandos, por carecerem de abordagens específicas e entenderem que é um assunto pertinente, fizeram apontamentos de como poderia ser levantada a discussão durante sua graduação. Essa foi considerada uma subcategoria emergente intitulada demandas para a formação. Eles citaram que:

Estudante 1- "Minha sugestão é essa que deve formar grupos de estudos na universidade para expandir essa ideia".

Estudante 5- "[...] eu acho que o curso teria sim que ter uma disciplina que atendesse a esse aspecto: a sexualidade [...] então eu acho que seria a hora do curso trazer. Ah, não dá para trazer disciplina não? Então traz palestra... A Semana da Biologia está aí, por que não coloca essa temática, está entendendo"?

Estudante 4- "Eu acho que para começar poderia ter amostra de trabalhos sobre o tema"

Essas sugestões reforçam o interesse dos estudantes pela temática e reafirmam a ausência de diálogo sobre identidade de gênero e sexuais na universidade pesquisada, corroborando o que a literatura especializada já aponta em relação à escassez de abordagens deste assunto em cursos de licenciatura de outras instituiçõos de ensino superior.

Os próprios formandos demandam saber onde buscar fontes para compreender melhor esse universo e conseguirem abordar o tema diversidade de gênero e sexual de maneira acolhedora, no exercício da profissão docente. Uma maneira interessante seria buscar fontes que dão visibilidade para quem protagoniza essa diversidade, isto é, a própria comunidade LGBTQIA+, para que possam compreender suas pautas e ter uma atitude mais sensível a essas pautas, enquanto educadores. As demandas dos formandos vão ao encontro do que diz Leão (2009 apud SILVA; SANTOS, 2011, p. 8), quando salienta que a

[...] formação inicial de professores, as licenciaturas, de modo geral, deveriam contemplar, no currículo, disciplinas que abordem a temática sexualidade, de maneira que os futuros docentes tenham acesso ao conhecimento necessário para a prática pedagógica. (LEÃO, 2009 apud SILVA; SANTOS, 2011, p. 8).

\subsection{Situações simuladas}


DOI:https://doi.org/10.33238/ReBECEM.2020.v.4.n.4.25592

A quarta categoria a priori, analisada a partir da ATD, foi denominada de situações simuladas. Foi proposto aos participantes que a mediadora faria a leitura de estórias de situações hipotéticas relacionadas à identidade de gênero ou sexual em sala de aula e os acadêmicos deveriam relatar como agiriam perante aquela situação. Essa proposta foi interessante para estimular a discussão entre eles. A primeira situação foi a seguinte: um estudante te aborda confessando que está sentindo atração sexual pelo seu colega de sala e te relata que está confuso (uma vez que ele se "desvia" do padrão de atração pelo sexo oposto). Como você lidaria com essa situação? Ao apresentar a situação, iniciaram-se as discussões e alguns pontuaram a relação da idade como um fator limitante para reagir à situação. Essa foi considerada uma subcategoria emergente. A seguir apresentamos alguns fragmentos de fala:

Estudante 9- "Então, eu acho que você tem que identificar primeiro que idade e que tipo de sentimento ele está tentando te relatar, aí acho que depois disso, que você vai buscar uma metodologia para tentar intervir [...]".

Estudante 4- "Mas eu concordo com isso, que tenha que adequar à idade. Tem certas coisas que eu não posso falar pra um menino de 11 anos, que eu poderia falar para um de 17".

A partir dos trechos, nota-se que alguns estudantes se preocuparam em saber qual a idade do menino da situação hipotética, a fim de decidirem como deveria ser a abordagem. A estudante 4 declarou que há "informações" que "não dá para tratar com estudantes muito novos": "eu não posso falar pra um menino de 11 anos o que eu poderia falar para um de 17". Porém, de acordo com o tema transversal "Orientação Sexual” do PCN (1998, p. 308), verifica-se que “da quinta série em diante, os alunos já apresentam condições de canalizar suas dúvidas ou questões sobre sexualidade para um momento especialmente reservado para tal, com um professor disponível". Salientamos que estamos nos referimos aos PCN, uma vez que desde a década de 1990 este documento trata a sexualidade como um tema transversal. No entanto, como enfatizado no início do trabalho, a BNCC (2018) que é a atual diretriz curricular brasileira, retirou de seu texto original várias passagens referentes à diversidade de gênero e sexual, o que caracteriza um retrocesso em relação à antiga diretriz curricular. Sabemos que a aprovação da BNCC resulta de um embate muito mais político do que pedagógico, que certamente trará consequências importantes para as novas gerações. A nosso ver, a temática sexualidade deve ser abordada no contexto escolar sempre que essa discussão emergir como uma necessidade do grupo. 
DOI:https://doi.org/10.33238/ReBECEM.2020.v.4.n.4.25592

Outros acadêmicos mencionaram que tentariam informar os estudantes independentemente da idade. Consideramos esse posicionamento como uma subcategoria emergente, que foi chamada de naturalizar o assunto. Ressaltamos que o termo "naturalizar" empregado neste trabalho implica em tratar a temática de forma espontânea, sem tabus e estigmas, de modo a não reforçar preconceitos presentes em nossa sociedade. Os acadêmicos citam que:

Estudante 3- "Eu não sei se eu concordei direito com essa história de faixa etária, porque não tem como a gente ficar privando a informação para o aluno [...] acho que é mais tranquilizar, buscar também uma forma de passar isso para os outros alunos também, sem expô-lo e tentar conscientizar os outros também que existem várias formas de gênero e de sexualidade".

Estudante 2- "Eu acho [...] que é bem aquilo de você falar com ele: ah, é normal! Não tem nada errado, você não é diferente, está tudo bem e é isso ai! E informar ele o máximo possível a respeito, justamente, de sexualidade no geral, sabe?! Falar com ele a questão da identidade de gênero".

Apesar de alguns estudantes sinalizarem que abordariam o assunto com o educando e que tentariam informá-lo ao máximo, por outro lado, houve um relato de um formando que disse que evitaria o assunto. Dessa forma, identificamos outra subcategoria emergente, que intitulamos dificuldades de abordagem. A seguir segue a fala do acadêmico:

Estudante 6- "eu tenho uma certa dificuldade de conversar sobre esses assuntos [...]. Porque eu acho bem delicado e eu não tenho muita preparação, e se for o caso eu digo com sinceridade que eu iria desviar desse aluno, assim, para conversar, mas não iria excluir o aluno... Mas esse assunto eu ia fugir".

O acadêmico relata que iria "desviar desse aluno, fugir do assunto", pois não se sente preparado, por ser um assunto "complicado de se tratar na sala de aula". Como citado na seção anterior, a respeito da formação acadêmica, a escassez da abordagem da temática durante a graduação impacta na atuação do futuro professor. Além disso, o acadêmico sequer cita que buscaria se informar para poder dialogar com o estudante hipotético, o que mostra a fragilidade da sua formação.

$\mathrm{Na}$ segunda situação simulamos que: em sua sala de aula há uma pessoa homossexual (lésbica/gay) ou bissexual e constantemente os colegas de sala zombam dela e a excluem. Como vocês reagiriam? Quando a situação foi exposta, os formandos começaram a debater e alguns apontaram que iriam tentar trabalhar o respeito. Identificamos essa como uma subcategoria emergente. Os acadêmicos apontaram: 
DOI:https://doi.org/10.33238/ReBECEM.2020.v.4.n.4.25592

Estudante 8- "Eu pediria respeito dos alunos que estão zombando, poderia estar falando: só porque ele tem uma opinião diferente da maioria que isso não torna ele pior que ninguém".

Estudante 1- "Eu tentaria trabalhar o respeito com aqueles alunos [...] Eu ia falar pra ele trabalhar a empatia, pra ele se colocar no lugar do colega".

Muitos dos formandos citaram que trabalhariam o respeito e a empatia somente, porém uma estudante apontou que:

Estudante 3- "Além de pedir respeito, seria a deixa para tratar o assunto".

Ou seja, a Estudante 3 entende que esta seria uma oportunidade ideal para abordar sobre as identidades sexuais e também de gênero. Em situações como essas é necessário ampliar o discurso sobre o respeito, pois o desconhecimento ocasiona o pré-conceito. Afinal, o que se deve respeitar? Qual é a origem do desrespeito? Discutir o que está por trás do preconceito é uma forma de problematizar as relações de poder imbricadas nas questões de gênero e sexualidade. Inferimos que a "deixa" na qual a Estudante 3 se refere deve relacionar-se ao assunto em pauta na reunião, isto é, a multiplicidade das identidades de gênero e sexuais.

Para a terceira e última situação simulamos que: no início do ano letivo uma estudante te aborda falando que na lista de chamada o nome dela está Pedro, mas que ela gostaria de ser chamada, tanto por você, tanto pelos colegas de sala, de Natália (pois ela é transexual). Como você explicaria essa situação para a sala? Os estudantes, perante essa situação, relataram que seria uma oportunidade para abordar sobre identidade de gênero, para que todos os estudantes tivessem conhecimento acerca do assunto. Acreditamos que essa intenção de informar pretende naturalizar as identidades. Os acadêmicos relataram:

Estudante 4- "Eu acho que é imprescindível a explicação das classificações de transexualidade, de cisgênero, ai tem que ter! Tem que ter. Não pode fugir".

Estudante 2- "Eu falaria e iria puxar a questão sobre pessoa transgênero e explicaria. Porque, igual eu falei, o negócio de você conhecer como funciona, o que é, você tira o preconceito".

Estudante 3- "[...] se em algum momento o preconceito sobressair era legal a gente trabalhar tanto a informação, quanto o respeito, quanto os valores, quanto tudo isso que a gente falou aqui... Sabe, aí ajudaria os alunos a superar os preconceitos".

Além da tentativa de explicação sobre o assunto, os formandos apontaram que dialogariam sobre o respeito e outros valores. Por mais que os formandos tenham relatado que durante a formação não tiveram acesso ao conhecimento sobre as identidades de gênero e sexuais, muitos deles demonstraram que debateriam o assunto na sala de aula e para isso teriam que buscar informações por conta própria. É bastante pertinente não 


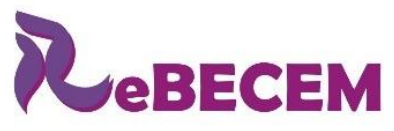

DOI:https://doi.org/10.33238/ReBECEM.2020.v.4.n.4.25592

ignorar situações como as que foram simuladas no GF, uma vez que no histórico das instituições escolares, essas temáticas são silenciadas. Esse silenciamento é destacado por Louro (2014), que entende a ausência de discussão sobre o assunto como a negação da existência de pessoas com identidades sexuais e de gênero diferentes da heterossexual e cisgênero, legitimando assim os insultos e tentando garantir uma "norma" inexistente.

\section{Conclusão}

Ao realizar o grupo focal para identificar as percepções dos formandos de um curso de Licenciatura em Ciências Biológicas de uma universidade federal mineira para lidar com as questões referentes às identidades de gênero e sexuais, buscamos entender a partir das percepções dos formandos, se o curso ou a universidade contribuíram para a formação dos mesmos em relação a estas questões. Por ser uma pesquisa exploratória, não tivemos a pretensão de realizar generalizações ou de trazer um conhecimento inédito, mas sim entender uma realidade específica na qual estão imersos os autores deste texto. Observamos nos relatos de alguns dos acadêmicos que o contato com a temática foi bastante pontual e, quando discutida, essa se ateve a um enfoque meramente biológico do corpo humano. Esses achados corroboram com Felipe e Guizzo (2004 apud SILVA; SANTOS, 2011), ao destacarem que nos cursos de licenciatura são raras as oportunidades de discutir sobre as identidades de gênero e sexuais.

Os acadêmicos ainda salientaram que devido ao pouco contato com a temática se sentem despreparados para discutirem o assunto com seus futuros estudantes, porém apontaram que, caso o tema venha a emergir durante sua atuação profissional, tentarão dialogar a respeito e buscarão por informações complementares. Os participantes da pesquisa afirmaram que os cursos de formação de professores, em especial o de Ciências Biológicas, deveriam abordar mais sobre esse assunto, pois, nas vivências nas escolas, eles perceberam que manifestações referentes às identidades de gênero e sexuais são recorrentes. Portanto, destacamos a importância das Práticas como Componente Curricular (PCC), dos Estágios Supervisionados e das disciplinas biológicas, específicas do curso, promoverem discussões que fujam do determinismo biológico, e que possam dar visibilidade à multiplicidade de identidades de gêneros e sexuais, para que os licenciados possam ter, durante seu exercício profissional, uma postura acolhedora e sem preconceitos ou estigmas. Destacamos também que discussões para além do enfoque 
meramente biológico são necessárias e fundamentais, uma vez que a sexualidade faz parte da vida humana, e se abster de tratar esse assunto na escola pode contribuir para reforçar comportamentos preconceituosos e discriminatórios, o que é intolerável numa sociedade que se quer justa, plural e democrática.

\section{Referências}

BEAUVOIR, S. de. O segundo sexo: a experiência vivida. Tradução de Sérgio Milliet, v. 2, 1967.

BONFIM, C. R. de S. Educação Sexual e Formação de Professores de Ciências Biológicas: contradições, limites e possibilidades. 2009. 272 f. Tese (Doutorado em Educação) -Faculdade de Educação, Universidade Estadual de Campinas, Campinas, 2009. Disponível em:< http://repositorio.unicamp.br/jspui/handle/REPOSIP/25174>. Acesso em: 20 ago. 2019.

BORGES, C. D.; DOS SANTOS, M. A. Aplicações da técnica do grupo focal: fundamentos metodológicos potencialidades e limites. São Paulo: Revista SPAGESP. V. 6, n 1, p 74-80. 2005.

BORTOLETTO, G. E. LGBTQIA+: identidade e alteridade na comunidade. São Paulo: USP, 2019.

BRASIL. Ministério da Educação. Base Nacional Comum Curricular. Brasília, DF: MEC, 2018.

BRASIL. Ministério da Educação. Plano Nacional de Educação. Brasília, DF: MEC, 2014.

BRASIL. Secretaria da Saúde. Decreto No 8.901/2016, de 11 de novembro de 2016. Institui a alteração da nomenclatura "IST" (infecções sexualmente transmissíveis) no lugar de "DST" (doenças sexualmente transmissíveis). Diário Oficial da União; Poder Executivo. Brasília: Ministério da Saúde, 2016.

BRASIL. Secretaria de Educação Fundamental. Parâmetros Curriculares Nacionais: terceiro e quarto ciclos do ensino fundamental: introdução aos parâmetros curriculares nacionais. Brasília: MEC/SEF, 1998.

CASTRO, A. T.; FELICIONI, F.; TÓDERO, B. M.; ALLAIN, L. R. O processo de formação de professores crítico-reflexivos a partir da utilização de diários de bordo no Pibid Biologia da Unifal-MG. Atas do VIII ENPEC-Encontro Nacional de Pesquisa em Educação em Ciências, 2011. 
CUNHA, L. R. da. Identidade e redesignação de gênero: aspectos da personalidade, da família e da responsabilidade civil. 1. ed. Rio de Janeiro: Lumen Juris, 2015.

DINIZ, B. L. R.; CIRINO, M. M.; HEREDERO, E. S. Formação inicial em educação sexual: percepções de professores de Biologia de um Instituto de Educação Secundária de Guadalajara (Espanha). Encontro Nacional de Pesquisa em Educação de Ciências-ENPEC, v. 10, 2015.

DE ARAUJO PENNA, F. O discurso reacionário de defesa do projeto "Escola sem Partido". Quaestio-Revista de Estudos em Educação, v. 20, n. 3, p. 567-581, 2018. Disponível em: <https://doi.org/10.22483/2177-5796.2018v20n3p567-581>. Acesso em: 06 fev. 2020.

DE JESUS, J. G. Orientações sobre identidade de gênero: conceitos e termos. Guia técnico sobre pessoas transexuais, travestis e demais transgêneros, para formadores de opinião. Brasília. 2012. Disponível em: <https://www.sertao.ufg.br/up/16/o/ORIENTA\%C3\%87\%C3\%95ES_POPULA\%C3\%87\%C3 \%83O_TRANS.pdf?1334065989>. Acesso em: 5 nov. 2019.

DE OLIVEIRA, M. L.; DE MENEZES FARIA, J. C. N. Formação inicial de professores: desafios e possibilidades do ensino de reprodução e sexualidade no estágio curricular supervisionado. Investigações em Ensino de Ciências, v. 16, n. 3, p. 509-528, 2016.

ESCOSTEGUY, A. C. Uma introdução aos Estudos Culturais. Revista FAMECOS, Porto Alegre, n. 9, dez, 1998. Disponível em:

<http://revistaseletronicas.pucrs.br/ojs/index.php/revistafamecos/article/view/3014/>. Acesso em: 5 nov. 2019.

GATTI, B. A. Grupo focal na pesquisa em Ciências sociais e Humanas. Brasília: Líber Livro Editora, Série Pesquisa em Educação 10. 2005.

HALL, S. A identidade cultural na pós-modernidade. TupyKurumin, 2006.

JUNQUEIRA, R. D. Homofobia nas escolas: um problema de todos. In. JUNQUEIRA, R. D. (Org.). Diversidade Sexual na Educação: problematizações sobre a homofobia nas escolas. Brasília: Ministério da Educação, Secretaria de Educação Continuada, Alfabetização e Diversidade, UNESCO, 2009. p. 13-52.

LEÃO, A. M. de C. Estudo analítico-descritivo do curso de pedagogia da UnespAraraquara quanto a inserção das temáticas de sexualidade e orientação sexual na formação de seus alunos. 2009. 343 f. Tese (Doutorado) - Curso de Pedagogia, Universidade Estadual Paulista, Araraquara, 2009. Disponível em: <https://repositorio.unesp.br/bitstream/handle/11449/101587/000603793.pdf?sequence=1\&isAll owed=y>. Acesso em: 05 nov. 2019. 
DOI:https://doi.org/10.33238/ReBECEM.2020.v.4.n.4.25592

LOURO, G. L. Gênero, sexualidade e Educação: uma perspectiva pós-estruturalista. 16. ed. Rio de Janeiro: Vozes, 2014.

MAISTRO, V. I. de A. Projeto de orientação sexual na escola: seus limites e possibilidades. 2006. 249f. Dissertação (Mestrado em Ciências e Educação Matemática) - Centro de Ciências Exatas, Universidade Estadual de Londrina, Londrina, 2006.

MANHAS, C. Nada mais ideológico que "Escola Sem Partido". In: AÇÃO EDUCATIVA, Assessoria, Pesquisa e Informação (Org.). A ideologia do movimento "Escola Sem Partido": 20 autores desmontam o discurso. São Paulo: Ação Educativa, p. 15-22, 2016.

MAZZOTTI, A. J. A. O planejamento de pesquisas qualitativas em educação. Cadernos de Pesquisa. n. 77, p. 53-61, maio 1991.

MORAES, R. Uma tempestade de luz: a compreensão possibilitada pela análise textual discursiva. Ciência e Educação. Bauru. v. 9, n. 2, p. 191-211. 2003. Disponível em: $<$ http://www.scielo.br/scielo.php?script=sci_arttext\&pid=S1516$73132003000200004 \& \operatorname{lng}=\mathrm{en} \& n r m=i$ so $>$. Acesso em: 20 ago. 2019.

MORAES, R.; GALIAZZI, M. do C. Análise textual discursiva: processo reconstrutivo de múltiplas faces. Ciência e Educação. Bauru. v. 12, n. 1, p. 117-128, abril 2006. Disponível em: $<$ http://www.scielo.br/scielo.php?script=sci_arttext\&pid=S1516-

73132006000100009\&lng=en\&nrm=iso>. Acesso em: 18 ago. 2019.

MORESCO, M. C.; RIBEIRO, R. O conceito de identidade nos estudos culturais britânicos e latino-americanos: um resgate teórico. Animus. Revista Interamericana de Comunicação Midiática, v. 14, n. 27, 2015. Disponível em: <https://periodicos.ufsm.br/animus/article/view/13570>. Acesso em: 22 ago. 2019.

OLIVEIRA, M. M. de. Como fazer Pesquisa Qualitativa. 3. ed. Petrópolis, RJ: Editora Vozes, p.41. 2008.

REIS, T.; EGGERT, E. Ideologia de gênero: uma falácia construída sobre os planos de educação brasileiros. Educação \& Sociedade, v. 38, n. 138, p. 9-26, 2017. Disponível em: <https://www.redalyc.org/articulo.oa?id=87350459002>. Acesso em: 22 ago. 2019.

SILVA, C. R.; GOBBI, B. C.; SIMÃO, A. A. O uso da análise de conteúdo como uma ferramenta para a pesquisa qualitativa: descrição e aplicação do método. Organizações Rurais \& Agroindustriais [online]. Lavras. v. 7, n. 1, p. 70-81, 2005. Disponível em: <http://www.redalyc.org/articulo.oa?id=87817147006>. Acesso em: 22 ago. 2019.

SILVA, L. M. M.; SANTOS, S. P. Sexualidade e Formação Docente: representações de futuros professores/as de Ciências e Biologia. VII Encontro Nacional de Pesquisa em Educação em Ciências, Campinas, 2011. Disponível em:

<http://www.nutes.ufrj.br/abrapec/viiienpec/resumos/R0835-1.pdf>. Acesso em: 22 ago. 2019. 
SILVA, T. T.; HALL, S.; WOODWARD, K. A produção social da identidade e da diferença. In: DA SILVA, T. T. (Org.). Identidade e diferença: a perspectiva dos estudos culturais. Petrópolis: Vozes, p. 73-102, 2000.

Recebido em: 12 de agosto de 2020

Aceito em: 12 de novembro de 2020 